\title{
Molecular characterisation of Heterorhabditis indica isolates from India, Kenya, Indonesia and Cuba
}

\author{
Colin M. Stack ${ }^{1}$, Subbana G. Easwaramoorthy ${ }^{2}$, Usha K. Metha ${ }^{2}$, Martin J. Downes ${ }^{1}$, \\ Christine T. GRIFFIN ${ }^{1}$ and Ann M. BURNELL ${ }^{1, *}$ \\ ${ }^{1}$ The Institute for Bioengineering and Agroecology, Department of Biology, National University of Ireland, Maynooth, \\ Co. Kildare, Ireland \\ ${ }^{2}$ Sugarcane Breeding Institute, Indian Councilfor Agricultural Research, Coimbatore, Tamil Nadu 641 007, India
}

Accepted for publication:20 November 1999

Summary - Isolates of Heterorhabditis were identified as $H$. indica using the following molecular diagnostic features: hybridisation to a $H$. indica specific satellite DNA probe; $A l u \mathrm{I}$ and $M b o \mathrm{I}$ restriction profiles of the rDNA ITS PCR product and the AluI profile of the rDNA IGS PCR product. The Kenyan isolates represent a distinct subgroup of $H$. indica. These isolates lacked one of the two Hinf I restriction sites which are present in the rDNA ITS product of all the other isolates tested and they also differed from other $H$. indica isolates in their rDNA IGS HaeIII restriction profile. The Indian isolates are interfertile. The Kenyan isolates are interfertile but only one Kenyan isolate, $\mathrm{Ki} 3$, produced viable progeny when crossed with $\mathrm{H}$. indica LN2. The four Indonesian isolates are interfertile, but only one Indonesian isolate (INA H1) produced viable hybrids when crossed with $H$. indica LN2. INA H1 was also interfertile with the Kenyan isolate Ki3.

Résumé - Caractérisation moléculaire d'isolats d'Heterorhabditis indica provenant d'Inde, du Kenya, d'Indonésie et de Cuba - Des isolats d'Heterorhabditis ont été identifiés comme $H$. indica par l'utilisation des techniques de caractérisation moléculaire suivantes: hybridation avec une sonde spécifique du DNA satellite de $H$. indica, produits des profils de restriction par PCR de l'ITS du rDNA par $A l u \mathrm{I}$ et $M b o \mathrm{I}$ et produit de PCR de l'IGS du rDNA par AluI. Les isolats keniyans constituent un sous-groupe distinct d' $H$. indica. Un des deux sites de restriction de Hinf I, présent dans les produits de l'ITS du rDNA de tous les autres isolats étudiés, est absent dans ces isolats qui différaient également dans leurs profils de restriction de l'IGS du rDNA par HaeIII. Les isolats d'Inde sont interfertiles. Les isolats kenyans sont inter-fertiles mais un seul de ces isolats, Ki3, a produit une descendance viable après croisement avec $H$. indica LN2. Les quatre isolats indonésiens sont interfertiles, mais un seul d'entre eux (INA H1) a produit des hybrides viables après croisement avec $H$. indica LN2. INA H1 a été également interfertile avec l'isolat kenyan Ki3.

Keywords - crossbreeding, DNA probe, entomopathogenic nematode, molecular diagnostics, rDNA ITS, rDNA IGS, satellite DNA.

Entomopathogenic nematodes (EPN) of the families Steinernematidae and Heterorhabditidae, together with their symbiotic bacteria Xenorhabdusspp. and Photorhabdus sp., respectively, are currently being mass produced commercially and used to control a variety of soil-dwelling insect pests in Europe, USA, Australia and China (see reviews by Kaya and Gaugler, 1993; Ehlers, 1996). The biological control potential of EPN has stimulated numerous surveys in an effort to find new indigenous isolates and possibly also new species of Heterorhabditis and Steinernema (reviewed by Hominick et al., 1996). Rapid and reliable diagnostic tests are required for species identification in such surveys and DNA fingerprinting techniques are now becoming more widely used as a first screen to determine the species composition of newly isolated EPN collections. These molecular approaches can then be supplemented by morphological, morphometric and crossbreeding techniques to confirm the identification of putative new species (reviewed by Hominick et al., 1997).

Although Steinernema and Heterorhabditis share many similarities in their mode of life and morphology, these similarities result from convergent evolution and are not indicative of a close phylogenetic relationship between the two families (Poinar, 1993; Sudhaus, 1993; Blaxter $e t$ al., 1998). Steinernema also appears to be more species rich than is Heterorhabditis. Twenty two Steinernema

*Corresponding author, e-mail: ann.burnell@may.ie 
species are recognised by Hominick et al. (1997). Adams et al. (1998) carried out a phylogenetic analysis based on rDNA internal transcribed spacer 1 DNA sequences of nine described species and one putative species of Heterorhabditis and they suggested that three pairs of sister taxa may be conspecific, thereby delimiting six species of Heterorhabditis. The study of Adams et al. (1998) did not include H. brevicaudis (Liu, 1994).

Current biogeographic data suggests that two species of Heterorhabditis, $H$. indica and $H$. bacteriophora, have a global distribution. $H$. indica occurs widely in the tropics and subtropics, having been isolated in southern India (Poinar et al., 1992); Sri Lanka (Amarasinghe et al., 1994); peninsular Malaysia (Mason et al., 1996); Indonesia (Griffin et al., 1999b); the Caribbean region (Arteaga Hernandez \& Mráček, 1984; Joyce et al., 1994a; Grenier et al., 1996a; Constant et al., 1998); Egypt (Grenier et al., 1996a) and in subtropical and warm temperate zones in Japan (Yoshida et al., 1998). Curran and Driver (1994) presented data for HaeIII restriction digests of the rDNA intergenic spacer region of a range of tropical isolates of Heterorhabditis from north Australia, Egypt, the Caribbean region, Florida, USA and Hawaii. They distinguished between two restriction profiles designated D1 and D1a. This distinction between the D1 and D1 a profiles was based on a size polymorphism of the large HaeIII restriction fragment from the rDNA IGS fragment.

H. bacteriophora occurs in regions of continental and Mediterranean climate in both the northern and southern hemispheres (reviewed by Hominick et al., 1996). To date, H. megidis has been recorded only from the northern hemisphere (Poinar et al., 1987; Smits et al., 1991; Miduturi et al., 1996; Menti et al., 1997; Yoshida et al., 1998; Griffin et al., 1999a), where it typically has a more northerly and more restricted distribution than $H$. bacteriophora, although $H$. megidis can be locally common in coastal regions of North West Europe (Griffin et al., 1999a). The remaining described species of Heterorhabditis appear to have a more restricted distribution: $H$. zealandica has been isolated in New Zealand and Tasmania (Wouts, 1979; Poinar, 1990; Curran \& Driver, 1994); H. marelatus has been isolated so far only in Oregon and California, USA (Liu \& Berry, 1996; Stock, 1997); H. brevicaudis has been isolated in south east China (Liu, 1994) and H. argentinensis in Argentina (Stock, 1993), although it is possible that $H$. argentinensis and $H$. bacteriophora may be conspecific (Adams et al., 1998). Heterorhabditis species distributions can also be influenced by altitude (Constant et al., 1998), soil type
(Kaya, 1990; Griffin et al., 1994) and vegetation cover (Strong et al., 1996).

We report here the isolation of new isolates of $H$. indica from India and Kenya. We have utilised a range of molecular diagnostic techniques in conjunction with crossbreeding in the identification of these new $H$. indica isolates and of isolates of $H$. indica previously isolated from India, Indonesia and Cuba. Our data indicate that the HaeIII rDNA IGS restriction profile designated D1a by Curran and Driver (1994) also occurs in the $H$. indica type species LN2 and that the Kenyan isolates represent a distinct subgroup within the D1 a group of $H$. indica.

\section{Materials and methods}

\section{NEMATOdE ISOLATES}

$H$. indica LN2, the $H$. indica type species (Poinar $e t$ al., 1992), is maintained at the Sugarcane Breeding Institute (SBI), Coimbatore, India. It was originally isolated from soil samples collected at Ramanathapuram $20 \mathrm{~km}$ north of Coimbatore, Tamil Nadu. Coimbatore (at $11^{\circ} \mathrm{N}$ latitude and $77^{\circ} \mathrm{E}$ longitude), is $120 \mathrm{~km}$ from the Arabian sea, $270 \mathrm{~km}$ from the Indian ocean and $310 \mathrm{~km}$ from the Bay of Bengal. The soil samples (soil type, red loam) were collected from fallow land (the previous crop was monsoon sorghum) and were baited in the laboratory with top borer (Scirpophaga excerptalis, Pyralidae: Lepidoptera) larvae. LN2B - in situ baiting with $S$. excerptalis larvae was carried out in a field at Somayanur, Coimbatore, from which groundnuts had been harvested. The soil type was red loam. The $S$. excerptalis larvae were placed individually in small plastic lids covered with brass wire mesh. The insect traps were left in the soil for four days and were then returned to the laboratory at SBI and checked for nematode infection. LN4 - this isolate was obtained from an infected white grub (Holotrichia serrata, Scarabaeidae: Coleoptera) larva collected from a sugarcane field at Thirupattur, $25 \mathrm{~km}$ north of Coimbatore. The soil type was heavy clay.

In collaboration with personnel from the Kenya Agricultural Research Institute (KARI), 21 soil samples, each of about $500 \mathrm{~g}$, were collected from five locations in coastal Kenya and two locations inland, in August 1994. One sample was taken near Tambia village, four from the WAU/KARI centre at Mtwapa, one from coral-based soil at an elevated $(8 \mathrm{~m}$ ) coastal site near Mombasa, 13 from vegetation fringing a beach at Kanamai, one from far inland in the south-west near Lolgorien, and one from near 
the Sand river in the same area as the last. The samples were flown to NUI Maynooth, where each sample was divided and each half was baited with five late instar Galleria mellonella larvae and incubated at $28^{\circ} \mathrm{C}$. Heterorhabditis isolates were recovered only at Kanamai, in a vegetation belt extending $15 \mathrm{~m}$ inland from the beach edge. Bioluminescent cadavers (indicating the presence of Heterorhabditis) were recovered from two of the 13 samples taken from there.

Four isolates were collected in a survey of five Indonesian islands by Griffin et al. (1999b).

Extracted DNA samples from four isolates displaying the D1a IGS restriction profile (FLGS10, JAM23, JAM79, ST09, ES10) were obtained from Dr Felice Driver (CSIRO, Canberra, Australia). The source and geographic origin of the other Heterorhabditis species and isolates included in this study are listed in Table 1.

\section{MOLECULAR CHARACTERISATION}

DNA was isolated according to Smits et al. (1991). The internal transcribed spacer (ITS) and intergenic spacer (IGS) regions of the rDNA cistron were amplified by means of the polymerase chain reaction (PCR) as described by Joyce et al. (1994a, b). Amplification products were digested with restriction endonucleases following the manufacturer's instructions using 5-12 $\mu$ l PCR product in a $15 \mu 1$ reaction volume. The entire digest was loaded on a $2 \%$ agarose gel and electrophoresed in $1 \times \mathrm{TBE}$ at $5 \mathrm{~V} / \mathrm{cm}$ for $3.5 \mathrm{~h}$. Restriction fragments were visualised by ethidium bromide staining.

The dot blot procedure utilised the $H$. indica speciesspecific satellite DNA probe used by Grenier et al. (1996a). Genomic DNA (100 ng) samples were denatured by adding $1 \mathrm{M} \mathrm{NaOH}$ and $200 \mathrm{~mm}$ EDTA $\mathrm{pH} 8.2$ to each sample to give a final concentration of $0.4 \mathrm{M} \mathrm{NaOH}, 10 \mathrm{mM}$

Table 1. Source and geographic origin of the Heterorhabditis species and isolates included in this study.

\begin{tabular}{|c|c|c|c|}
\hline Species & Isolate & Geographic Origin & Source \\
\hline H. indica & LN2 & Coimbatore, India & Easwaramoorthy ${ }^{1}$ \\
\hline H. indica & LN2B & Coimbatore, India & This study \\
\hline H. indica & LN4 & Coimbatore, India & This study \\
\hline H. indica & Ki3 & Kanami, Kenya & This study \\
\hline H. indica & $\mathrm{K} 4 \mathrm{~A}$ & Kanami, Kenya & This study \\
\hline H. indica & INA H1 & West Java, Indonesia & Griffin et al. (1999b) \\
\hline H. indica & INA H9 & Ambon, Indonesia & Griffin et al. (1999b) \\
\hline H. indica & INA H17 & Seram, Indonesia & Griffin et al. (1999b) \\
\hline H. indica & INA H23 & Moluccas, Indonesia & Griffin et al. (1999b) \\
\hline H. indica & $\mathrm{P} 2 \mathrm{M}$ & Artemisia, Cuba & Mracek $^{2}$ \\
\hline H. indica & D1 & Darwin, Australia & Bedding ${ }^{3}$ \\
\hline H. indica & FLGS10 & Florida, USA & Curran $\&$ Driver $^{3}$ \\
\hline H. indica & JAM23 & Jamaica & Curran \& Driver \\
\hline H. indica & JAM79 & Jamaica & Curran \& Driver \\
\hline H. indica & ST09 & Virgin Islands & Curran \& Driver \\
\hline H. indica & ES10 & Egypt & Curran \& Driver \\
\hline H. bacteriophora & HP88 & Utah, USA & Akhurst $^{3}$ \\
\hline H. zealandica & NZH3 & New Zealand & Bedding ${ }^{3}$ \\
\hline H. marelatus & $\mathrm{OH}-10$ & Oregon, USA & $\mathrm{Liu}^{4}$ \\
\hline H. hepialus & Bodega Bay & California, USA & Stock $^{5}$ \\
\hline H. megidis & HL81 & Leeuwarden, The Netherlands & Westerman ${ }^{6}$ \\
\hline$H$. 'Irish type' & K122 & Wexford, Ireland & Griffin et al. (1994). \\
\hline
\end{tabular}

${ }^{1}$ Sugar Cane Breeding Institute, Coimbatore, India;

${ }^{2}$ Institute of Entomology, Czech Academy of Sciences, Ceske Budejovice, Czech Republic;

${ }^{3}$ CSIRO, Canberra, Australia;

${ }^{4}$ Oregon State University, OR, USA;

${ }^{5}$ University of California, Davis, CA, USA;

${ }^{6}$ Van Hall Instituut, Leeuwarden, The Netherlands. 
EDTA and the samples were then boiled for $10 \mathrm{~min}$ in a water bath. The samples were then transferred by vacuum suction onto a positively charged nylon membrane (Amersham Life Sciences Ltd., Amersham, Buckinghamshire, UK) in a slot blot apparatus (Schleicher \& Schuell, D37582 Dassel, Germany) as per manufacturer's instructions. The DNA was then fixed onto the nylon membrane by UV cross-linking using Stratagene's Stratalinker (Stratagene, La Jolla, CA 92037, USA). The recombinant pUC plasmids Hi12 and HP88s9 which contained respectively the $H$. indica and $H$. bacteriophora satellite DNA monomers were obtained from Dr Pierre Abad, INRA, Antibes, France and amplified using PCR. The PCR primers used to amplify the $H$. indica monomer from the Hi12 plasmid were $5^{\prime}$-CTGAAGCACTTGGGACAGAGC- $3^{\prime}$ and 5'-CTCCTCGTTGAGGACGGGAGT3' (Abadon et al., 1998; Grenier, pers. comm.). The H. bacteriophora monomer was amplified from the HP88s9 plasmid using the following PCR primers $5^{\prime}$-AGCTATGCCAGAATGATCGCC-3' and 5'-AGATTCTCTGTACGATGAGTA-3' (Grenier et al., 1996b; Grenier, pers. comm.). DNA was amplified using the following conditions: one cycle of $94^{\circ} \mathrm{C}$ for $5 \mathrm{~min}$ was followed by 35 cycles of denaturation at $94^{\circ} \mathrm{C}$ for 0.5 min annealing at $52^{\circ} \mathrm{C}$ for $1 \mathrm{~min}$ and extension at $72^{\circ} \mathrm{C}$ for $2 \mathrm{~min}$, with a final cycle of extension at $72^{\circ} \mathrm{C}$ for $5 \mathrm{~min}$.

The probes were labelled using the ECL direct nucleic acid detection system (Amersham) following the manufacturer's instructions. Hybridisations were conducted at $42^{\circ} \mathrm{C}$ overnight. After hybridisation, the filters were washed first with $0.5 \times \mathrm{SSC}$ for $40 \mathrm{~min}$ at $42^{\circ} \mathrm{C}$ and then with $0.1 \times \mathrm{SSC}$ for $5 \mathrm{~min}$ at room temperature. After posthybridisation washes, filters were exposed to HyperflimECL (Amersham) following the manufacturer's instructions. The membrane was then stripped and reprobed using an $18 \mathrm{~S}$ rDNA probe as a loading control. The $18 \mathrm{~S}$ probe was obtained by PCR from $H$. indica $\mathrm{LN} 2$ genomic DNA using the primers: 18SR2B 5'-TACAAAGGGCAGGGACGTATT-3' and 18S1.2 5'-GGCGATCAGATACCGCCCTAGTT-3' (T.O. Powers, pers. comm.).

\section{CROSS-BREEDING TESTS}

Cross-breeding studies were carried out as described by Dix et al. (1992) with the following controls being set up for each cross: virginity test -20 virgin females were placed on a lipid agar plate that had been inoculated and pre-incubated with the primary form of the LN2 bacteria; self-cross - ten virgin females and ten males of the same isolate were placed on lipid agar plates containing the bacterial symbiont. The result of any cross between different isolates was taken as valid only if there were no progeny in the virginity test and there were progeny in the self-cross. At least ten second generation virgin females were used for each cross.

\section{Results}

RESTRICTION PROFILES OF THE RDNA INTERNAL TRANSCRIBER SPACER (ITS) REGION

All of the tropical isolates of Heterorhabditis yielded a $c a 1 \mathrm{~kb}$ fragment upon PCR amplification with the ITS primers. These amplification products were digested with the diagnostic restriction endonucleases used by Joyce et al. (1994a) for species diagnosis in Heterorhabditis (viz. AluI, Hinf I and MboI). When digested with AluI (Fig. 1) the Indian isolates LN2B and LN4 shared the same restriction profile as the $H$. indica $\mathrm{LN} 2$ type species, as did the Indonesian isolates, the P2M isolate from Cuba, and the Kenyan isolates. When digested with $\mathrm{MboI}$, the Kenyan isolates shared the same restriction profile

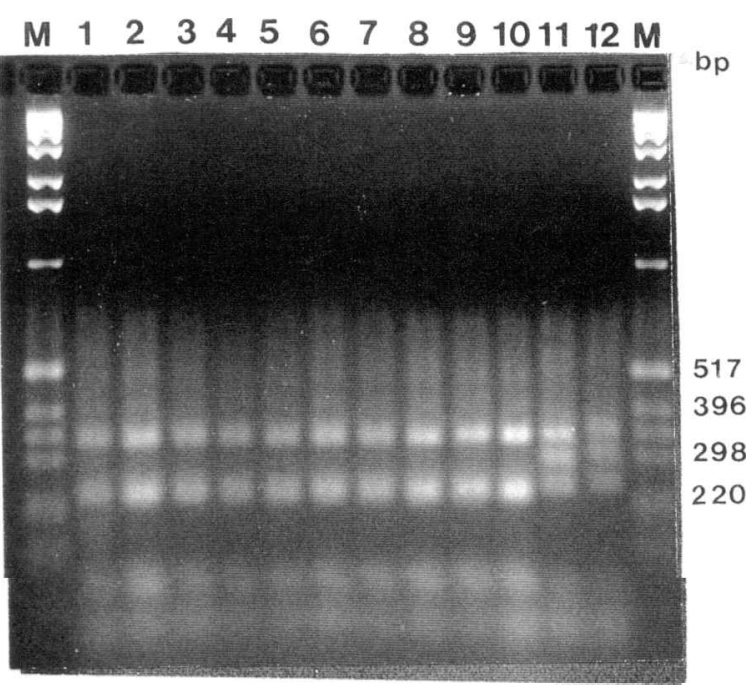

Fig. 1. AluI restriction digests of the PCR amplification products of the rDNA internal transcribed spacer region of Heterorhabditis isolates, separated on a $2 \%$ agarose gel and stained with ethidium bromide. $M$ : $1 \mathrm{~kb}$ marker; $1: \mathrm{H}$. indica $L N 2$; 2: P2M; 3: LN2B; 4: LN4; 5: INA H23; 6: INA H9; 7: INA H17; 8: INA H1; 9: Ki3; 10: K4A; 11: Heterorhabditis 'Irish type' K122; 12: H. megidis $H L 81$. 
as $H$. indica $\mathrm{LN} 2$ and $\mathrm{P} 2 \mathrm{M}$ (Fig. 2). The Indonesian isolates also displayed the same $\mathrm{MboI}$ restriction profile as $H$. indica LN2 (data not shown). When digested with Hinf I (Fig. 3) the Indian, Indonesian and Cuban isolates but not the Kenyan isolates, possessed the same restriction profile as $H$. indica LN2. The Kenyan isolates have only a single $\operatorname{Hinf} \mathrm{I}$ restriction site in the ITS rDNA fragment, yielding two restriction fragments of $c a 620$ and $450 \mathrm{bp}$, unlike all the other $H$. indica isolates tested, which possess two Hinf I sites in this region, yielding three restriction fragments of $c a 450,360$ and $240 \mathrm{bp}$.

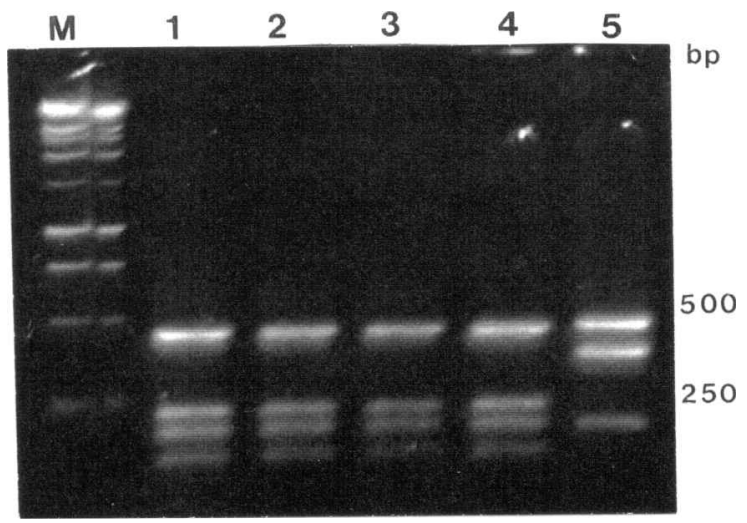

Fig. 2. $\mathrm{MboI}$ restriction digests of the PCR amplification products of the rDNA internal transcribed spacer region of Heterorhabditis isolates, separated on a $2 \%$ agarose gel and stained with ethidium bromide. $M: 1 \mathrm{~kb}$ marker; 1 : $\mathrm{H}$. indica LN2; 2: P2M; 3: Ki3; 4: K4A; 5: H. bacteriophora HP88.

\section{RESTRICTION PROFILES OF THE RDNA INTERGENIC SPACER (IGS) REGION}

The PCR amplification products for the IGS rDNA region of the tropical isolates varied in size from $1.5 \mathrm{~kb}$ to $1.7 \mathrm{~kb}$. The amplified IGS rDNA fragments were restricted with the endonucleases AluI and HaeIII. A diagnostic $A l u \mathrm{I}$ restriction pattern was obtained for $H$. indica LN2 and this was shared by all the Indian, Indonesian, Cuban and Kenyan isolates (Fig. 4) and the D1 and D1a type isolates (Fig. 6). When HaeIII was used to digest the IGS rDNA region, $H$. indica $\mathrm{LN} 2$ displayed a distinctive five fragment profile of 740, 280, 190, 160 and $120 \mathrm{bp}$ (Fig. 5) and, with the exception of the Kenyan isolates, four of these fragments were shared by the other tropical isolates. The Kenyan isolates Ki3 (lane 9) and K4A (lane 10) had a distinct restriction profile yielding HaeIII fragments of 700, 280 (a doublet), 185 and $120 \mathrm{bp}$. The largest $H$. indica Hae III fragment was highly polymorphic in size between the tropical isolates, ranging in size from 700 to $850 \mathrm{bp}$, with some isolates having fragments of intermediate size ca $740 \mathrm{bp}$. Size polymorphismin this fragment was the basis on which the types D1 and D1a were recognised by Curran and Driver (1994). The HaeIII profiles of the other three species of Heterorhabditisincluded in Fig. 5 were all distinctly different from that of $H$. indica. As can be seen from Fig. 6, the HaeIII rDNA IGS restriction profile designated D1a by Curran and Driver (1994) (lanes 4-7) is similar to that of $H$. indica LN2, but the HaeIII pattern of the Kenyan isolates (Fig. 6, lane 3; Fig. 5, lanes 9,10) is unique.

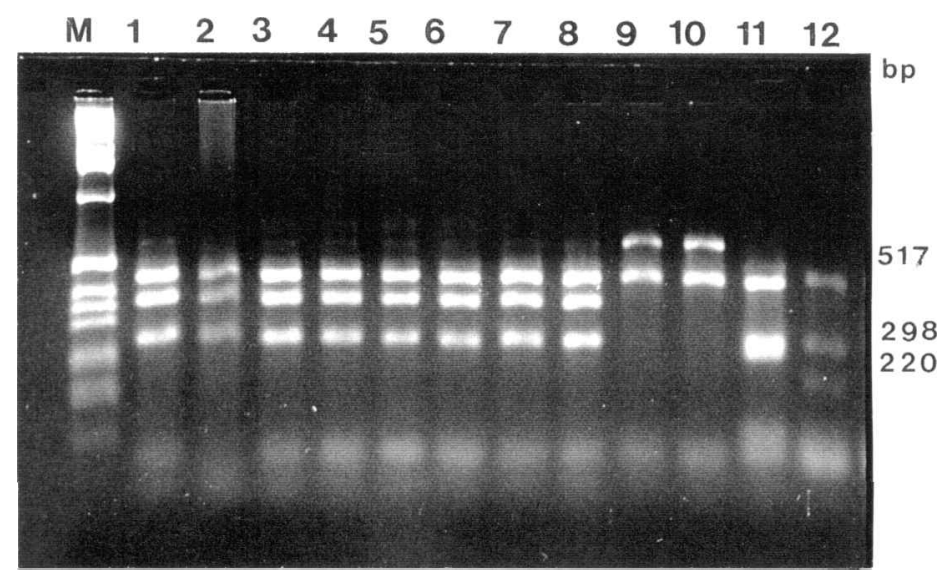

Fig. 3. HinfI restriction digests of the PCR amplification products of the rDNA internal transcribed spacer region of Heterorhabditis isolates, separated on a $2 \%$ agarose gel and stained with ethidium bromide. M: $1 \mathrm{~kb}$ marker; $1:$ LN2; 2: P2M; 3: LN2B; 4: LN4; 5: INA H23; 6: INA H9; 7: INA H17; 8: INA H1; 9: Ki3; 10: K4A; 11: Heterorhabditis 'Irish type' K122; 12: H. megidis HL81. 


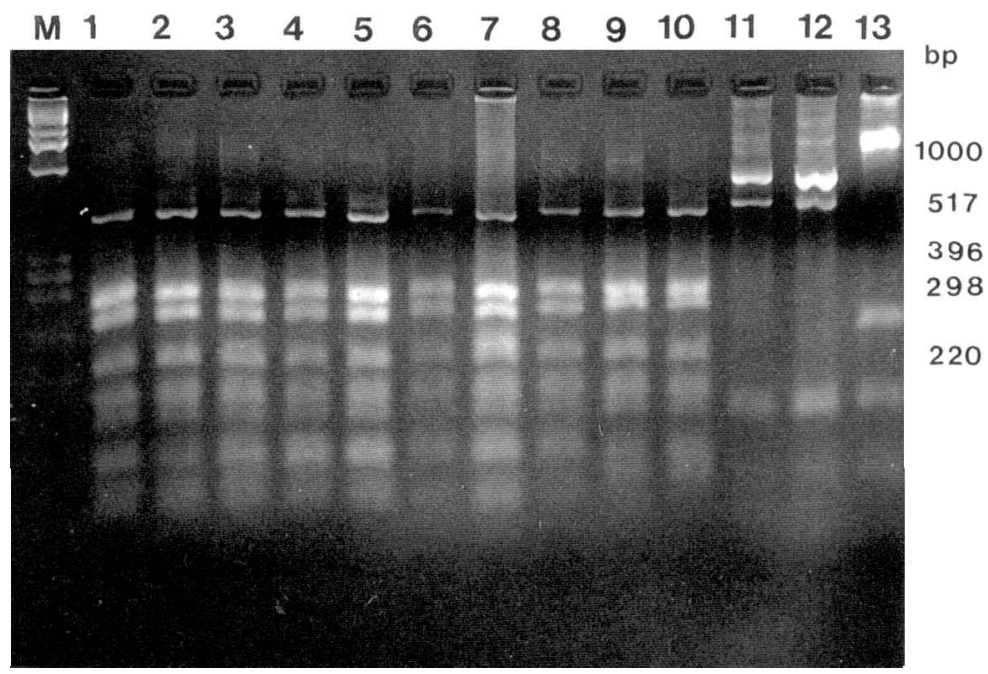

Fig. 4. AluI restriction digests of the PCR amplification products of the rDNA intergenic spacer region of Heterorhabditis isolates, separated on a $2 \%$ agarose gel and stained with ethidium bromide. M: $1 \mathrm{~kb}$ size marker; $1: L N 2 ; 2: P 2 M ; 3: L N 2 B ; 4: L N 4$; 5: INA H23; 6: INA H9; 7: INA H17; 8: INA H1; 9: Ki3; 10: K4A; 11: Heterorhabditis 'Irish type' K122; 12: H. megidis HL81; 13: H. bacteriophora $H P 88$.

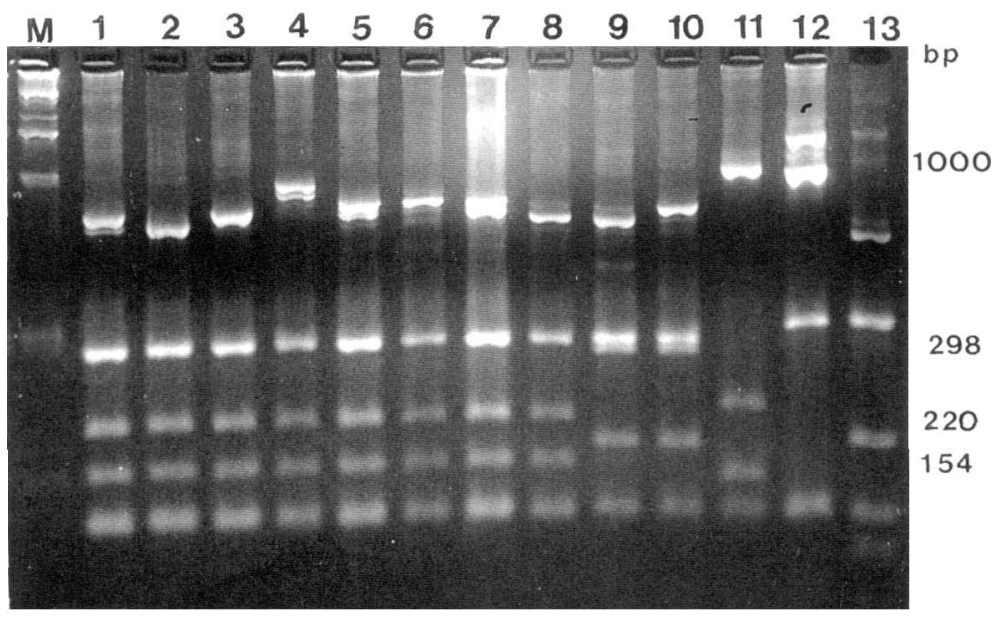

Fig. 5. HaeIII restriction digests of the PCR amplification products of the rDNA intergenic spacer region of Heterorhabditis isolates, separated on a $2 \%$ agarose gel and stained with ethidium bromide. M: 1 kb size marker; 1 : LN2; 2: P2M; 3: LN2B; 4: LN4; 5: INA H23; 6: INA H9; 7: INA H9; 8: INA H1; 9: Ki3; 10: K4A; 11: Heterorhabditis 'Irish type' K122; 12: H. megidis HL81; 13: H. bacteriophora HP88.

USE OF H. INDICA SPECIES SPECIFIC SATELLITE DNA PROBE

When Southern blots of total genomic DNA of the tropical isolates were probed with the $H$. indica speciesspecific satellite DNA probe described by Abadon et al. (1998), the probe hybridised only with the isolates classified from PCR analysis as being $H$. indica, including the Kenyan isolates Ki3 and K4A (Fig. 7A). No hybridisation was detected by this probe to any of the other species included as controls on the Southern blot. This blot was then reprobed with the H. bacteriophora specific satellite DNA probe described by Grenier et al. (1996), and this probe hybridised only with the HP88 isolate of $H$. bacteriophora included on the Southern blot (data not shown). 


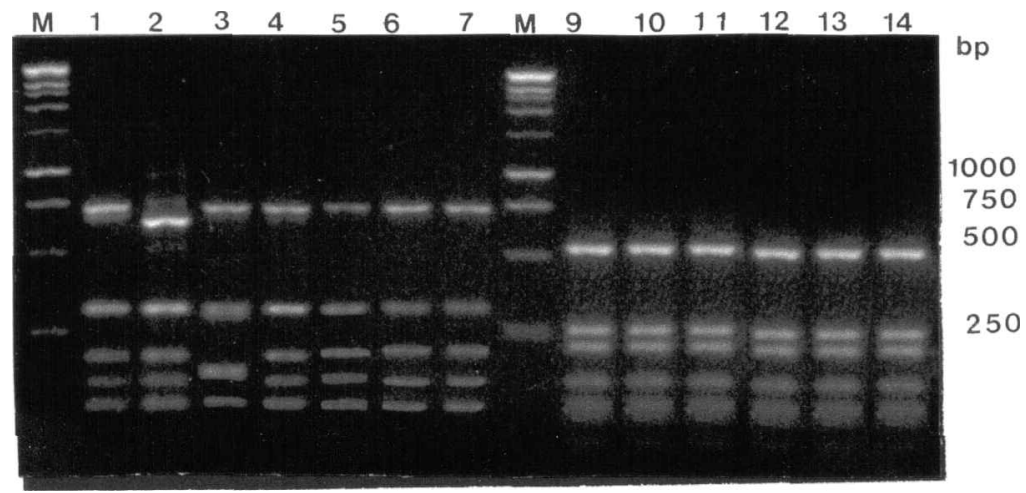

Fig. 6. HaeIII and AluI restriction digests of the PCR amplification products of the rDNA intergenic spacer region of Heterorhabditis isolates, including isolates designated type D1 a by Curran and Driver (1994). M: 1kb size marker; 1: H. indica LN2; 2: D1; 3: K4A; 4: ES10; 5: JAM79; 6: ST09; 7: FLGS10; M: 1 kb marker; 9: H. indica LN2; 10: D1; 11: ES10; 12: JAM79; 13: ST09; 14: FLGS10. Lanes 1 to 7 contain HaeIII digests and lanes 9 to 14 contain AluI digests. The digests were separated on a 2\% agarose gel and stained with ethidium bromide.

Table 2. The results of cross-breeding experiments of six Heterorhabditis isolates from India, Indonesia and Kenya.

\begin{tabular}{lcccccc}
\hline Female & \multicolumn{7}{c}{ Male } \\
\cline { 2 - 7 } & $\begin{array}{c}\text { H. indica } \\
\text { LN2 } \\
\text { India }\end{array}$ & Lndia & INA H1 & INA H23 & Ki3 & K4A \\
& Indonesia & Indonesia & Kenya & Kenya \\
\hline H. indica & + & + & + & 0 & + & 0 \\
$\quad$ LN2 & & & & & & \\
LN 4 & + & + & 0 & 0 & + & + \\
INA H1 & + & + & + & + & + & 0 \\
INA H23 & 0 & 0 & + & + & 0 & 0 \\
Ki3 & + & + & + & 0 & + & + \\
K4A & 0 & 0 & 0 & 0 & + & + \\
\hline
\end{tabular}

+ cross resulted in fertile progeny;

0 no progeny detected.

\section{CROSS BREEDING ANALYSIS}

Selected cross-breeding results are presented in Table 2. All the Indian isolates are interfertile. The Kenyan isolates, which differed from $H$. indica in their HinfI ITS restriction profile and their HaeIII IGS restriction profile, are interfertile amongst each other but only one Kenyan isolate, $\mathrm{Ki} 3$, produced viable progeny when crossed with the $H$. indica $\mathrm{LN} 2$ type species. The Indonesian isolates are interfertile, but surprisingly, only one of the Indonesian isolates tested (INA H1) produced viable hybrids when crossed with $H$. indica LN2. The INA H1 isolate was also interfertile with the Kenyan isolate Ki3.

\section{Discussion}

The results presented here confirm and extend previous studies which show that a combination of molecular diagnostic tools can be reliably used for species identification in Heterorhabditis. Isolates of Heterorhabditis from India, Kenya, Indonesia and Cuba hybridised to the $H$. indica specific satellite DNA probe (Grenier et al., 1996; Abadon et al., 1998). H. indica specific DNA restriction profiles were also obtained for all the tropical isolates of Heterorhabditis investigated here when the ITS rDNA region was restricted using the diagnostic restriction enzymes AluI and MboI (Joyce et al., 1994a). The utility of restriction digests of the rDNA ITS region in species diagnosis of EPN has been confirmed in several studies (Joyce et al., 1994a, b; Miduturi et al., 1996; Hominick et al., 1997; Yoshida et al., 1998; Griffin et al., 1999a; Pamjav et al., 1999). Restriction of the rDNA IGS region with $A l u \mathrm{I}$ also yielded a $H$. indica specific restriction profile for all the tropical isolates tested in this study.

The PCR amplification product which we obtained for the $H$. indica rDNA IGS varied in size from 1.2 to $1.6 \mathrm{~kb}$. Hominick et al. (1997) also observed length heterogeneity in the rDNA IGS region among geographic isolates of single Steinernema spp. and they suggested that this heterogeneity may make restriction profiles of this DNA fragment unreliable for species identification. The length heterogeneity which we detected in the $H$. indica IGS PCR amplification product did not affect the AluI restriction profile of the product and a clear-cut seven restriction fragment pattern was common to all the $H$. indica isolates 


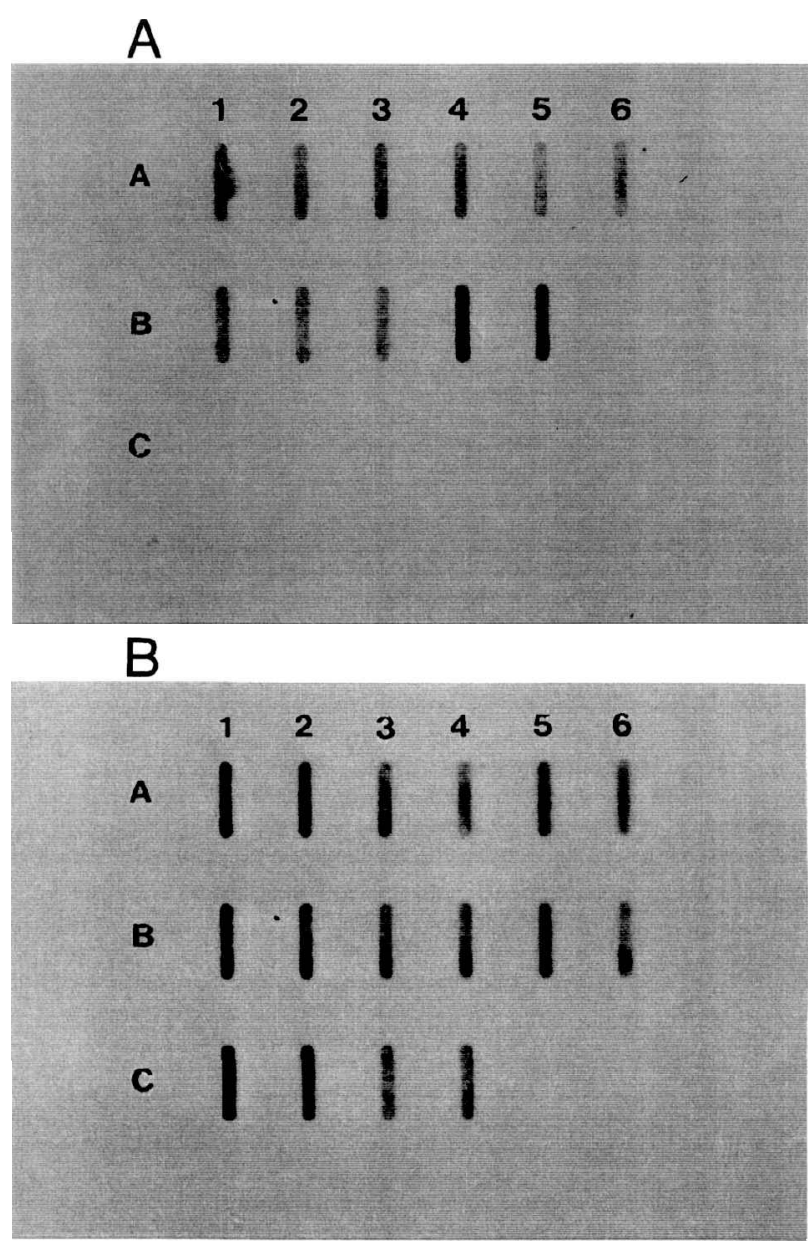

Fig. 7. A: Slot blot analysis of genomic DNA (100 $\mathrm{ng}$ ) of the Heterorhabditis isolates using a $\mathrm{H}$. indica specific satellite DNA probe; B: The membrane used for Fig. 7A was stripped and reprobed using an rDNA $18 S$ probe as a loading control. A1: H. indica LN2; A2: D1; A3: P2M; A4: LN2B; A5: LN4; A6: INA H23; B1: INA H9; B2: INA H17; B3: INA H1; B4: Ki3; B5: $K 4 A$; B6: H. bacteriophora $H P 88$; $C 1$ : H. zealandica $N Z H 3$; C2: H. marelatus $\mathrm{OH}-10$; $\mathrm{C3}$ : H. hepialus Bodega Bay; C4: Heterorhabditis 'Irish type' K122.

tested. When the IGS region was digested with HaeIII, $H$. indica LN2 displayed a distinctive five fragment profile. All of the $H$. indica isolates, with the exception of the Kenyan isolates, also displayed a five fragment profile. Four of these fragments were conserved among the isolates, but the largest fragment (of $\mathrm{ca} 740 \mathrm{in} \mathrm{H}$. indica LN2) was polymorphic among the $H$. indica isolates. This fragment, which seems to be associated with the length polymorphism in the $H$. indica IGS region, is the basis of the D1/D1 a polymorphism observed by Curran and
Driver (1994). In most species studied to date, the rDNA IGS contains tandem arrays of subrepeats (Gerbi, 1985; Williams et al., 1990; Vahidi \& Honda, 1991; Novak et al., 1993; Linares et al., 1994; Crease, 1995). This results in the length of the IGS region being variable both between and within species. The length heterogeneity of the $H$. indica IGS PCR product did not affect the AluI restriction profile of this fragment, which suggests that Alu $\mathrm{I}$ has a restriction site within a tandem repetitive unit in the rDNA IGS of $H$. indica. In contrast, HaeIII appears not to cut within this tandem repeat region with the result that one of the HaeIII restriction fragments is polymorphic, its length presumably depending on the number of AluI repeat units which it contains.

The HaeIII rDNA IGS restriction profile of the D1a isolate is similar to that of $H$. indica LN2, but the HaeIII pattern of the Kenyan isolates is unique. The large HaeIII fragment of the Kenyan isolate K4A is the same size as that of D1a, thus the Kenyan isolates appear to represent a distinct subgroup within D1a. Tropical isolates from Darwin (North Australia), Puerto Rico, Hawaii, the Virgin Islands and Egypt were found by Curran and Driver (1994) to possess the D1 profile, while the D1a profile was described by these authors from isolates collected in Puerto Rico, Jamaica, Florida, the Virgin Islands and Egypt. Comparison of the D1 and D1a HaeIII and AluI rDNA IGS restriction profiles with those of $H$. indica LN2, indicates that the isolates designated D1 and D1a by Curran and Driver (1994) belong to $H$. indica.

An important step towards achieving an effective nematode bacterium complex for pest control is to seek naturally occurring endemic EPN isolates, as such isolates are likely to possess physiological traits that are adapted to local climatic and ecological conditions. The Kenyan isolates described in this study clearly belong to a distinct sub-group of $\mathrm{H}$. indica and it is probable that these isolates also share a distinctive phenotype. The two Kenyan isolates are interfertile but only one of these isolates (Ki3) produced viable progeny when crossed with the $H$. indica LN2 type species. All of the Indonesian Heterorhabditis isolates were indistinguishable from $H$. indica in the diagnostic molecular tests and they were interfertile with each other, but only one of the Indonesian isolates (INA $\mathrm{H} 1$ ) was interfertile with $H$. indica LN2 and INA H1 was also interfertile with the Ki3 isolate from Kenya. These results suggest that, although $H$. indica has a global distribution in tropical and subtropical regions of the world, geneflow within the species may be quite restricted. We have previously observed reproductiveincompatibilitybe- 
tween isolates of $H$. bacteriophora from Europe (Griffin et al., 1999a) and from North America (Dix et al., unpubl.). We have not determined whether this reproductive isolation is caused by genetic means or is the result of cytoplasmic factors. Cytoplasmic factors such as endosymbiont bacteria (see reviews by Werren, 1997; Johanowicz \& Hoy, 1998) and chromosomal factors such as transposons (reviewed by Kidwell, 1990; Petrov et al., 1995) have been shown to be frequent causes of reproductive incompatibility in arthropods. Endosymbiont bacteria have recently been shown to cause reproductive incompatibility in filarial nematodes (Hoerauf et al., 1999). Since the reproductive incompatibility observed in this study does not yield clear groups of compatible and incompatible strains and in view of the consistency of the DNA based diagnostic tests, any assignment of biological species within the $H$. indica group would be injudicious at present. Adams (1988) evaluates phylogenetic and biological species concepts in the delimitation of species in the H. bacteriophora group.

The global distribution of $H$. indica throughout the tropics and subtropics suggests that $H$. indica possesses a range of phenotypic characters which give it an advantage in this climatic zone. Such phenotypes might include adaptation to high temperatures, desiccation tolerance and good dispersal ability. It is unlikely that the widespread distribution of $H$. indica in the tropics arises because this species was extant before the continents began breaking up and drifting. The best supported hypothesis of phylogenetic relationships among Heterorhabditis species, in a phylogeny derived from the rDNA ITS 1 DNA sequence data, puts $H$. indica as the most ancient Heterorhabditis lineage (Adams et al., 1998). However, the phylogenetic tree for Heterorhabditis and Steinernema of Reid (1994) shows that the genetic distance between Heterorhabditis species is considerably less than that between Steinernema species and given the small genetic distance detected by Reid (1994) between the most divergent of the Heterorhabditis species in his study (a $\mathrm{D}$ value of $c a$ 0.04 as calculated by the method of Nei and Li, 1979), it seems unlikely that $H$. indica speciated before the Jurassic/Cretaceous break up of Pangaea (an estimated 200 million years ago).

\section{Acknowledgement}

We acknowledge the support of the European Community STD-3 Programme (TS3 CT 940273).

\section{References}

Abadon, M., Grenier, E., Laumond, C. \& Abad, P. (1998). A species-specific satellite DNA from the entomopathogenic nematode Heterorhabditis indicus. Genome 41, 148-153.

ADAms, B.J. (1998). Species concepts and the evolutionary paradigm in modern nematology. Journal of Nematology 30 , $1-21$.

Adams, B.J., Burnell, A.M. \& Powers, T.O. (1998). A phylogenetic analysis of the genus Heterorhabditis (Nemata: Rhabditidae) based on internal transcribed spacer 1 DNA sequence data. Journal of Nematology 30, 22-39.

Amarasinghe, L.D., Hominick, W.M., Briscoe, B.R. \& REID, A.P. (1994). Occurrence and distribution of entomopathogenic nematodes in Sri Lanka. Journal of Helminthology 68, 277-286.

Arteaga Hernandez, E.M. \& Mráček, Z. (1984). Heterorhabditis heliothidis, a parasite of insect pests in Cuba. Folia Parasitologia (Praha) 31, 11-17.

Blaxter, M.L., De Ley, P,. Garey, J.R., Liu, L.X., Scheldeman, P., Vierstraete, A., Vanfleteren, J.R., MACKey, L.Y., Dorris, M., FrisSe, L.M., VidA, J.T. \& ThомAS, W.K. (1998). A molecular evolutionary framework for the phylum Nematoda. Nature 392, 71-75.

Constant, P., Marchay, L., Fisher-Le Saux, M., BRIAND-PANOMA, S., \& MAUlÉON, H. (1998). Natural occurrence of entomopathogenic nematodes (Rhabditida: Steinernematidae and Heterorhabditidae) in Guadeloupe islands. Fundamental and Applied Nematology 21, 667-672.

Crease, T.J. (1995). Ribosomal DNA evolution at the population-level - nucleotide variation in intergenic spacer arrays of Daphnia pulex. Genetics 141, 1327-1337.

CuRran, J. \& Driver, F. (1994). Molecular taxonomy of $\mathrm{He}$ terorhabditis. In: Burnell, A.M., Ehlers, R-U. \& Masson, J.P. (Eds). Genetics of Entomopathogenic Nematode-Bacterium Complexes. Luxembourg, European Commission Publication EUR $15681 \mathrm{EN}$, pp. 178-187.

Dix, I., Burnell, A.M., Griffin, C.T., Joyce, S.A., \& Downes, M.J. (1992). The identification of biological species in the genus Heterorhabditis (Nematoda: Heterorhabditae) by cross-breeding second generation amphimictic adults. Parasitology 104, 509-518.

EHLERs, R.-U. (1996). Current and future use of nematodes in biocontrol: practice and commercial aspects with regard to regulatory policy issues. Biocontrol Science and Technology 6, 303-317.

GERBI, S.A. (1985). Evolution of ribosomal DNA. In: MacIntyre, R.J. (Ed.) Molecular evolutionary genetics. New York, NY, USA, Plenum Press, pp. 419-517.

Grenier, E., Bonifassi, E., Abad, P. \& Laumond, C. (1996a). Use of species specific satellite DNAs as diagnostic probes in the identification of Steinernematidae and 
Heterorhabditidae entomopathogenic nematodes. Parasitology 113, 483-489.

Grenier, E., Laumond, C., \& ABAD, P. (1996b). Molecular characterisation of two species-specific tandemly repeated DNAs from entomopathogenic nematodes Steinernema and Heterorhabditis (Nematoda: Rhabditida). Molecular and Biochemical Parasitology 83, 47-56.

Griffin, C.T., Joyce, S.A., Dix, I. Burnell, A.M. \& DownEs, M.J. (1994). Characterisation of the entomopathogenic nematode Heterorhabditis (Nematoda: Heterorhabditidae) from Ireland and Britain by molecular and crossbreeding techniques, and the occurrence of the genus in these islands. Fundamental and Applied Nematology 17, 245-253.

Griffin, C.T., Dix, I., Joyce, S.A., Burnell, A.M. \& Downes, M.J. (1999a). Isolation and characterisation of Heterorhabditis spp. from Hungary, Estonia and Denmark. Nematology 1, 321-332.

Griffin, C.T., Chaerani, R., Fallon, D., Reid, A.P. \& Downes, M.J. (1999b). Occurrence and distribution of the entomopathogenic nematodes Steinernema spp. and Heterorhabditis indica in Indonesia. Journal of Helminthology 74, 143-150.

Hoerauf, A., Nissenpahle, K., Schmetz, C., HenKleduhrsen, K., Blaxter, M.L., Buttner, D.W., Gallin, M.Y., Alqaoud, K.M., Lucius, R. \& FleisCHER, B. (1999). Tetracycline therapy targets intracellular bacteria in the filarial nematode Litomososoides sigmodontis and results in filarial infertility. Journal of Clinical Investigation 103, 11-17.

Hominick, W.M., Reid, A.P. Bohan, D.A. \& Briscoe, B.R. (1996). Entomopathogenic nematodes: biodiversity, geographical distribution and convention on biological diversity. Biocontrol Science and Technology 6, 317-332.

Hominick, W.M., Briscoe, B.R., Del Pino F.G., Heng, J., Hunt, D.J., Kozodoy, E., MráČek, Z., NGuyen, K.B., Reid, A.P., Spiridonov, S., Stock, P., Sturhan, D., Waturu, C. \& Yoshida, M. (1997). Biosystematics of entomopathogenic nematodes: current status, protocols and definitions. Journal of Helminthology 71, 271-298.

Johanowicz, D.L. \& Hoy, M.A. (1998). The manipulation of arthropod reproduction by Wolbachia endosymbionts. Florida Entomologist 81, 310-317.

Joyce, S.A., Burnell, A.M. \& Powers, T.O. (1994a). The characterisation of Heterorhabditis isolates by restriction enzyme analysis of PCR amplified fragments of mtDNA and rDNA genes. Journal of Nematology 26, 260-270.

Joyce, S.A., Reid, A. \& Curran, J. (1994b). Application of the polymerase chain reaction (PCR) methods to the identification of entomopathogenic nematodes. In: Burnell, A.M., Ehlers, R.-U. \& Masson, J.P.(Eds). Genetics of entomopathogenic nematode-bacterium complexes. Luxembourg, European Commission Publication EUR 15681 EN, pp. 178-187.
KAYA, H.K. (1990). Soil ecology. In: Gaugler, R. \& Kaya, H.K. (Eds). Entomopathogenic nematodes in biological control. Boca Raton, FL, USA, CRC Press, pp. 93-115.

KAYA, H.K. \& GAugler, R. (1993). Entomopathogenic nematodes. Annual Review of Entomology 38, 181-206.

KIDWELL, M.G. (1990). Evolutionary aspects of hybrid dysgenesis in Drosophila. Canadian Journal of Zoology 68, 17161726.

Linares, A.R., Bowen, T. \& Dover, G.A. (1994). Aspects of non-random turnover involved in the concerted evolution of intergenic spacers within the ribosomal DNA of Drosophila melanogaster. Journal of Molecular Evolution 39, 151-159.

LIU, J. (1994). [A new species of the genus Heterorhabditis from China (Rhabditida: Heterorhabditidae).]Acta Zootaxonomica Sinica 19, 268-272.

LIU, J. \& BERRY, R.E. (1996). Heterorhabditis marelatus n.sp. (Rhabditida: Heterorhabditidae) from Oregon. Journal of Invertebrate Pathology 67, 48-54.

Mason, J.M., RazAK, A.R. \& Wright, D.J. (1996). The recovery of entomopathogenic nematodes from selected areas within Peninsular Malaysia. Journal of Helminthology 70, 303-307.

Menti, H., Wright, D.J. \& PerRy, R.N. (1997). Desiccation survival of populations of the entomopathogenic nematodes Steinernema feltiae and Heterorhabditis megidis from Greece and the UK. Journal of Helminthology 71, 41-46.

Miduturi, J.S., Moens, M., Hominick, W.M., Briscoe, B.R. \& REID, A.P. (1996). Naturally occurring entomopathogenic nematodes in the province of West-Flanders, Belgium. Journal of Helminthology 70, 319-327.

NEI, M. \& LI, W.-H. (1979). Mathematical model for studying genetic variation in terms of restriction endonucleases. Proceedings of the National Academy of Sciences of the United States 76, 5269-5273.

NovaK, E.M., De Mello, M.P., Gomes, H.B.M., Galindo, I., Guevara, P., Ramirez J.L. \& Da SilveRIA J.F. (1993). Repetitive sequences in the ribosomal intergenic spacer of Trypanosoma cruzi. Molecular and Biochemical Parasitology 60, 273-280.

Pamjav, H., Triga, D. Buzas, Z., Vellai, T., Lucskai, A., Adams, B., Reid, A.P., Burnell, A.M., Griffin, C., Glazer, I., Klein, M.G. \& Fodor, A. (1999). Novel application of PhastSystem polyacrylamide gel electrophoresis using restriction fragment length polymorphism-internal transcribed spacer patterns of individuals for molecular identification of entomopathogenic nematodes. Electrophoresis, 20,1266-1273.

Petrov, D.A., Schutzman, J.L., Hartl, D.L., \& LoZOVSKAYA, E.R. (1995). Diverse transposable elements are mobilised in hybrid dysgenesis in Drosophila virilis. Proceedings of the National Academy of Sciences of the United States 92, 8050-8054. 
PoInAR, G.O. JR. (1990). Taxonomy and biology of Steinernematidae and Heterorhabditidae. In: Gaugler, R. \& Kaya, H.K. (Eds). Entomopathogenic nematodes in biological control. Boca Raton, FL, USA, CRC Press, pp. 23-64.

POINAR, G.O. JR. (1993). Origins and phylogenetic relationships of the entomophilic rhabditids Heterorhabditis and Steinernema. Fundamental and Applied Nematology 16, 333 338.

Poinar, G.O. JR., Jackson, T. \& Klein, M. (1987). Heterorhabditis megidis sp. n. (Heterorhabditidae: Rhabditida) parasitic in the Japanese beetle Popillia japonica (Scarabidae: Coleoptera), in Ohio. Proceedings of the Helminthological Society of Washington 53, 53-59.

Poinar, G.O. JR., KarunakAR, G.K. \& DaVid, H. (1992). Heterorhabditis indicus n. sp. (Rhabditida: Nematoda) from India: Separation of Heterorhabditis spp. by infective juveniles. Fundamental and Applied Nematology 15, 467-472.

REID, A.P. (1994). Molecular taxonomy of Steinernema. In: Burnell, A.M., Ehlers, R.-U. \& Masson, J.P. (Eds). Genetics of entomopathogenic nematode-bacterium complexes. Luxembourg, European Commission Publication EUR 15681 EN, pp. 178-187.

Smits, P., Groenen, J.T.M. \& DeraAy, G. (1991). Characterisation of Heterorhabditis isolates using DNA restriction length polymorphism. Revue de Nématologie 14, 445-453.

STock, S.P. (1993). A new species of thegenus Heterorhabditis Poinar, 1976 (Nematoda: Heterorhabditidae) parasitizing Graphognathus sp. larvae (Coteoptera: Curculionidae) from Argentina. Research and Reviews in Parasitology 53, 103107.

S Tock, S.P. (1997). Heterorhabditis hepialus Stock, Strong \& Gardner, 1996a junior synonym of $H$. marelatus Liu \& Berry, 1996 (Rhabditida: Rhabditidae) with a redescription of the species. Nematologica 43, 455-463.
Stock, S.P., Strong, D. \& GARdner, S. (1996). Identification of Heterorhabditis (Nematoda: Heterorhabditidae)from California with a new species isolated from the larvae of the ghost moth Hepialius [sic] californicus (Lepidoptera: Hepialidae) from Bodega Bay Natural Reserve. Fundamental and Applied Nematology 19, 585-592.

Strong, D.R., KayA, H.K., Whipple, A.V., Child, A.L., Kraig, S., Bondonne, M., Dyer, K. \& Maron, J.L. (1996). Entomopathogenic nematodes: natural enemies of root feeding caterpillars on bush lupine. Oecologica 108, 3945.

SudHAUs, W. (1993). Die mittels symbiontischer Bakterien entomopathogenen Nematoden Gattungen Heterorhabditis and Steinernema sind keine Schwestertaxa. Verhandlungen der Deutschen Zoologischen Gesellschaft 86, 146.

VAHIDI, H. \& HONDA, B.M. (1991). Repeats and subrepeats in the intergenic spacer of rDNA from the nematode Meloidogyne arenaria. Molecular and General Genetics 227, 334336.

Werren, J.H. (1997). Biology of Wolbachia. Annual Review of Entomology 42, 587-609.

Williams, S.M., Robbins, L.G., Cluster, P.D., AlLARD, R.W. \& StRobeck, C. (1990). Superstructure of the Drosophila ribosomal gene family. Proceedings of the $\mathrm{Na}$ tional Academy of Sciences of the United States 87, 31563160 .

Wouts, W.M. (1979). The biology and life cycle of a New Zealand population of Heterorhabditis heliothidis ( $\mathrm{He}-$ terorhabditidae). Nematologica 25, 191-202.

Yoshida, M., Reid, A.P., Briscoe, B.R., \& Hominick, W.M. (1998). Survey of entomopathogenic nematodes (Rhabditida: Steinernematidae and Heterorhabditidae) in Japan. Fundamental and Applied Nematology 21, 185-198. 